\title{
Control failure likelihood and spatial dependence of insecticide resistance in the tomato pinworm, Tuta absoluta
}

\author{
Gerson A Silva, ${ }^{a}$ Marcelo C Picanço, ${ }^{a}$ Leandro Bacci, ${ }^{b}$ André Luiz B Crespo, ${ }^{a}$ \\ Jander F Rosado ${ }^{\mathrm{a}}$ and Raul Narciso C Guedes ${ }^{\mathrm{a}}{ }^{*}$
}

\begin{abstract}
BACKGROUND: Insecticide resistance is a likely cause of field control failures of Tuta absoluta, but the subject has been little studied. Therefore, resistance to ten insecticides was surveyed in seven representative field populations of this species. The likelihood of control failures was assessed, as well as weather influence and the spatial dependence of insecticide resistance.

RESULTS: No resistance or only low resistance levels were observed for pyrethroids (bifenthrin and permethrin), abamectin, spinosad, Bacillus thuringiensis and the mixture deltamethrin + triazophos $(<12.5$-fold). In contrast, indoxacarb exhibited moderate levels of resistance (up to 27.5 -fold), and chitin synthesis inhibitors exhibited moderate to high levels of resistance (up to 222.3-fold). Evidence of control failures was obtained for bifenthrin, permethrin, diflubenzuron, teflubenzuron, triflumuron and $B$. thuringiensis. Weather conditions favour resistance to some insecticides, and spatial dependence was observed only for bifenthrin and permethrin.

CONCLUSION: Insecticide resistance in field populations of the tomato pinworm prevails for the insecticides nowadays most frequently used against them - the chitin synthesis inhibitors (diflubenzuron, triflumuron and teflubenzuron). Local selection favoured by weather conditions and dispersal seem important for pyrethroid resistance evolution among Brazilian populations of $T$. absoluta and should be considered in designing pest management programmes.
\end{abstract}

(c) 2011 Society of Chemical Industry

Keywords: insect growth regulators; insecticide resistance distribution; vegetable crops; Brazil; pest control

\section{INTRODUCTION}

The tomato pinworm Tuta absoluta (Meyrick) (Lepidoptera: Gelechiidae) is native to South America, from the region circumscribed by Ecuador, the Andes mountain range north of the Chilean border and the Pacific coast. ${ }^{1}$ It is the main tomato insect pest in South America, 2,3 and was introduced in Europe in 2006 through Spain. From Spain it quickly spread throughout most of Europe and soon reached Mediterranean Africa, where it has caused large tomato crop losses., ${ }^{4,5}$

The tomato pinworm larva compromises tomato productivity by consuming the leaf mesophyll and damaging the stalk, flowers and fruits. ${ }^{2,3,6}$ The consequence of such losses has been extensive insecticide field use (and overuse) to minimise the damage caused by the pinworm. However, insecticide applications are not always as efficient as expected for controlling this insect pest species. ${ }^{7,8}$ The evolution of insecticide resistance in South American populations of the pinworm is one reason for the low insecticide control efficacy. ${ }^{8-12}$

There are only a few studies focusing on the detection of insecticide resistance among populations of $T$. absoluta. Resistance to abamectin, cartap, methamidophos and permethrin were reported earlier in Brazil, ${ }^{8-10}$ while resistance to abamectin, deltamethrin and methamidophos were also detected later in Argentina. ${ }^{12}$ Resistance to organophosphates and pyrethroid insecticides were also reported in Chile. ${ }^{11,13}$ These studies, however, do not go beyond the survey of insecticide resistance and eventual study of mechanisms of abamectin and cartap resistance using insecticide synergists. ${ }^{9,10}$ They neglected the potential influence of weather on insecticide resistance and its spatial distribution, which can potentially allow the recognition of main areas prone to problems of insecticide resistance.

The objective of the present study was to survey resistance levels of representative populations of the tomato pinworm T. absoluta from the main tomato-producing regions in Brazil to the main insecticides currently used and recommended. Furthermore, the likelihood of insecticide control failures in the surveyed insect populations was assessed, as well as weather influence and the spatial dependence of insecticide resistance in the tomato pinworm.

\footnotetext{
Correspondence to: Raul Narciso C Guedes, Departamento de Biologia Animal, Universidade Federal de Viçosa, Viçosa, MG 36571-000, Brazil. E-mail:guedes@ufv.br

a Departamento de Biologia Animal, Universidade Federal de Viçosa, Viçosa, MG, Brazil

b Departamento de Engenharia Agronômica, Universidade Federal de Sergipe, Aracaju, SE, Brazil
} 


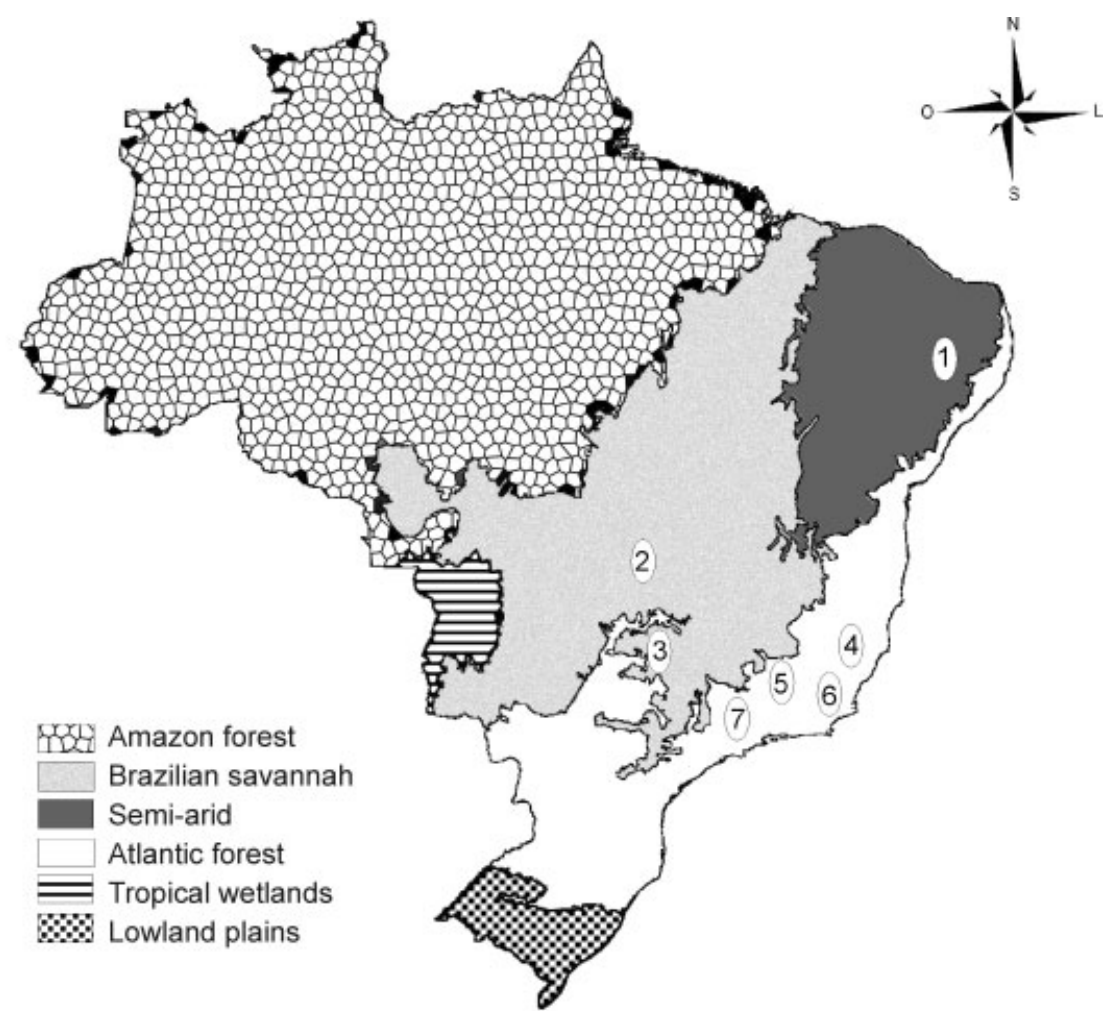

\begin{tabular}{|c|c|c|c|c|c|c|}
\hline \multirow{2}{*}{ Sampling sites } & \multirow{2}{*}{$\begin{array}{l}\text { Geographic } \\
\text { coordinates }\end{array}$} & \multicolumn{3}{|c|}{ Temperature $\left({ }^{\circ} \mathrm{C}\right)$} & \multirow{2}{*}{$\begin{array}{c}\text { Rain } \\
\left(\text { mm year }^{-1}\right)\end{array}$} & \multirow{2}{*}{$\begin{array}{l}\text { Insolation } \\
\begin{array}{l}\text { (h) }\end{array}\end{array}$} \\
\hline & & maximum & average & minimum & & \\
\hline 1- Camocim de São Félix, PE & $\begin{array}{l}08^{\circ} 211^{\prime} 32^{*} \mathrm{~S} \\
35^{\circ} 45^{\prime} 43^{\mathrm{W}} \mathrm{W}\end{array}$ & 30.0 & 22.50 & 15.0 & 986 & 7.40 \\
\hline 2 Goianápolis, GO & $\begin{array}{l}16^{\circ} 30^{\prime} 38^{\circ} \mathrm{S}, \\
49^{\circ} 01^{\prime} 26^{\mathrm{W}}\end{array}$ & 29.9 & 23.8 & 17.7 & 1300 & 6.67 \\
\hline 3-Uberlândia, MG & $\begin{array}{l}18^{\circ} 56^{\prime} 27^{\circ} \mathrm{S}, \\
48^{\circ} 09^{\prime} 15 \mathrm{~W}\end{array}$ & 24.7 & 23.0 & 18.8 & 1550 & 6.80 \\
\hline 4-Santa Tereza, ES & $\begin{array}{l}19^{\circ} 56^{\prime} 08^{\circ} \mathrm{S}, \\
40^{\circ} 36^{\prime} 01^{\prime} \mathrm{W}\end{array}$ & 30.0 & 20.0 & 16.0 & 1400 & 6.03 \\
\hline 5-Viçosa, MG & $\begin{array}{l}20^{\circ} 45^{\prime} 14^{\circ} \mathrm{S}, \\
42^{\circ} 52^{\prime} 55^{\prime} \mathrm{W}\end{array}$ & 26.0 & 20.0 & 14.0 & 1220 & 6.10 \\
\hline 6-Săo João da Barra, RJ & $\begin{array}{l}21^{\circ} 38^{\prime} 25^{\circ} \mathrm{S}, \\
41^{\circ} 03^{\prime} 04 \mathrm{~W}\end{array}$ & 27.5 & 23.1 & 21.0 & 1250 & 5.90 \\
\hline 7- Paulinia, SP & $\begin{array}{l}22^{\circ} 45^{\prime} 40^{\circ} \mathrm{S}, \\
47^{\circ} 09^{\prime} 15 \mathrm{~W}\end{array}$ & 28.1 & 21.7 & 15.3 & 1359 & 7.12 \\
\hline
\end{tabular}

Figure 1. Sampling sites of the field populations of the tomato pinworm Tuta absoluta.

\section{MATERIAL AND METHODS}

\subsection{Insect populations}

The tomato pinworm populations were collected in commercial tomato fields from seven different sites belonging to three Brazilian biomes - semi-arid, Brazilian savannah and Atlantic forest (Fig. 1). These biomes represent the Brazilian macroregions of tomato cultivation. The laboratory colonies were established from at least 200 field-collected individuals from each sampling site and maintained in large numbers to minimise loss of genetic variability. The populations were reared in a laboratory at $25 \pm 0.5^{\circ} \mathrm{C}$, with a relative air humidity of $75 \pm 5 \%$ and a photophase of $12 \mathrm{~h}$. Each population was reared in four wooden cages $(40 \times 40 \times 40 \mathrm{~cm})$ covered with organza: one for oviposition, one with first- and second-instar larvae, one with third- and fourth-instar larvae and one for pupation and adult emergence. The larvae were fed with tomato leaves from plants of the Santa Clara cultivar, cultivated under greenhouse conditions without any insecticide application. ${ }^{14}$ Only insects reared for at least one generation in the laboratory (usually between two and four) were used in the bioassays to prevent expression of insecticide tolerance due to the distinct environmental conditions at the sampling sites (i.e. without a genetic basis).

\subsection{Insecticides}

Ten insecticides were used in the present study. Six insecticides were neurotoxic (concentration of active ingredient indicated): abamectin $18 \mathrm{~g} \mathrm{~L}^{-1}$ EC (emulsifiable concentrate) (Syngenta, São Paulo, Brazil), bifenthrin $100 \mathrm{~g} \mathrm{~L}^{-1}$ EC (FMC Brasil, Campinas, Brazil), deltamethrin $10 \mathrm{~g} \mathrm{~L}^{-1} \mathrm{EC}+$ triazophos $350 \mathrm{~g} \mathrm{~L}^{-1}$ EC (Bayer SA, São Paulo, Brazil), indoxacarb $300 \mathrm{~g} \mathrm{~L}^{-1}$ WG (water-dispersible granules) (Du Pont, Barueri, Brazil), permethrin $500 \mathrm{~g} \mathrm{~L}^{-1}$ EC (Syngenta, São Paulo, Brazil) and spinosad $480 \mathrm{~g} \mathrm{~L}^{-1} \mathrm{SC}$ (suspendable concentrate) (Dow AgroSciences, São Paulo, Brazil). Three were insect growth regulators inhibiting chitin synthesis: diflubenzuron $250 \mathrm{~g} \mathrm{~L}^{-1}$ WP (wettable powder) (Crompton Ltd, Rio Claro, Brazil), teflubenzuron $150 \mathrm{~g} \mathrm{~L}^{-1} \mathrm{SC}$ (BASF, Guaratinguetá, Brazil) and triflumuron $250 \mathrm{~g} \mathrm{~L}^{-1}$ WP (Bayer, São Paulo, Brazil). The remaining insecticide consisted of spores of the bacterium Bacillus 
thuringiensis var. kurstaki strain HD-1 (33.60 g L${ }^{-1}$ SC; $17600 \mathrm{iu} \mathrm{g}^{-1}$; Abbott Laboratories/FMC Química Brasil Ltda, Uberada, Brazil). These products represent the main groups of insecticides recommended for managing the tomato pinworm in Brazil, except for the insecticide mixture deltamethrin + triazophos, which was being tested against this insect. ${ }^{15,16}$

\subsection{Insecticide resistance bioassays}

Two distinct strategies for concentration - response bioassays were carried out, one for neurotoxic insecticides and the other for chitin synthesis inhibitors and $B$. thuringiensis. This was necessary because neurotoxic insecticides exhibit quick action and affect all larval instars of T. absoluta. In contrast, chitin synthesis inhibitors and $B$. thuringiensis exhibit stronger activity against the first- and second-instar larvae but exhibit slower insecticidal activity than neurotoxic insecticides. ${ }^{17,18}$

\subsubsection{Neurotoxic insecticides}

Tomato leaflets were immersed for $5 \mathrm{~s}$ in insecticide solution and shade dried for $2 \mathrm{~h}$. The leaves were subsequently placed in petri dishes ( $9 \mathrm{~cm}$ diameter $\times 2 \mathrm{~cm}$ height) with inner walls coated with Teflon ${ }^{\circledR}$ PTFE (DuPont, Wilmington, DE) to prevent insect escape. Ten third-instar larvae were placed in each (open) petri dish, which was placed into a rearing chamber at $25 \pm 0.5^{\circ} \mathrm{C}, 75 \pm 5 \%$ relative humidity and $12 \mathrm{~h}$ photoperiod. Insect mortality was assessed after $48 \mathrm{~h}$ of exposure, and a larva was considered to be dead if unable to crawl the length of its body when prodded with a fine paint brush. A total of 6-10 different concentrations of each insecticide were used, besides the control where only water was used (to correct for natural mortality). Four replicates were used for each concentration and insecticide, and the bioassays were carried out following a completely randomised design. The bioassays for each insecticide were simultaneously performed under the same conditions, as detailed above.

\subsubsection{Growth-regulating insecticides and B. thuringiensis}

The experimental design was also completely randomised and simultaneously carried out for each insecticide, but with three replicates for each concentration and insecticide. Each replicate encompassed a $2 \mathrm{~L}$ plastic PET bottle containing a tomato leaf previously immersed in insecticide solution. The leaf petiole was kept immersed in a $100 \mathrm{~mL}$ glass flask with water. Each bottle had a $10 \times 15 \mathrm{~cm}$ hole to allow larva introduction, after which it was covered with organza to prevent insect escape. Twenty second-instar larvae were released in each bottle. Insect mortality was assessed after 7 days of exposure.

\subsubsection{Data analysis}

Concentration-mortality results were subjected to probit analysis, correcting the data for natural mortality (PROC PROBIT). ${ }^{19}$ Resistance ratios were determined on the basis of the $\mathrm{LC}_{50}$ using the most susceptible population as reference. The $95 \%$ confidence intervals for resistance ratios were estimated following Robertson and Preisler, ${ }^{20}$ and considered significant if not including the value 1.

\subsection{Assessment of potential insecticide control failure}

The assessment of potential insecticide control failure was carried out using the same experimental units as described for the concentration-response bioassays and comparing the mortality caused by the recommended label rate of each insecticide (midconcentration from the registered range) and the lower threshold at $\mathrm{LC}_{80}$ estimated for each compound. The $80 \%$ mortality was used as reference because this is the minimum level of efficacy required for registration of an insecticidal compound in Brazil by the Ministry of Agriculture. ${ }^{21}$ Therefore, this is the minimum expected level of efficacy without control failure due to insecticide resistance. The insecticide mortality caused by the label rate was considered to be significantly lower than $80 \%$ when the recommended rate was lower than the lower threshold of the $95 \%$ fiducial interval of the $\mathrm{LC}_{80}$ of the insecticide for the tested insect population. The registered and recommended label rates of the respective active ingredients in Brazil were: $0.18 \mathrm{mg} \mathrm{mL}^{-1}$ for abamectin, $0.072 \mathrm{mg} \mathrm{mL}^{-1}$ for B. thuringiensis, $0.05 \mathrm{mg} \mathrm{mL}^{-1}$ for bifenthrin, $0.032 \mathrm{mg} \mathrm{mL}^{-1}$ for deltamethrin + triazophos (preliminary recommendation), $0.4 \mathrm{mg} \mathrm{mL}^{-1}$ for diflubenzuron, $0.024 \mathrm{mg} \mathrm{mL}^{-1}$ for indoxacarb, $0.5 \mathrm{mg} \mathrm{mL}^{-1}$ for permethrin, $0.06 \mathrm{mg} \mathrm{mL}^{-1}$ for spinosad, $0.0375 \mathrm{mg} \mathrm{mL}^{-1}$ for teflubenzuron and $0.15 \mathrm{mg} \mathrm{mL}^{-1}$ for triflumuron.

\subsection{Relationship between weather conditions and insecticide resistance}

The annual average data of weather variables [namely air temperature (minimum, average and maximum), relative air humidity, rainfall, wind speed, photoperiod and insolation] were collected for each insect sampling site. The weather variables exhibiting significant correlation with the $\mathrm{LC}_{50}$ values $(P<0.05)$ were subjected to principal component analysis (PCA) using the Canoco 4.5 system and following Ter Braak. ${ }^{22}$ The biplot ordination gradient was generated with Canodraw 3.0. The gradients of response were represented by vectors with the origin at the central point of the two axes of the ordination diagram. The vector length is proportional to the variable importance. Vectors with the same direction and orientation represent variables with positive correlation, while vectors with the same direction and opposite orientation represent negative correlation. Variables are not correlated when the angle between the vectors is $90^{\circ}$.

\subsection{Spatial dependence of insecticide resistance}

The semi-variance statistical model of the $L C_{50}$ values of insect population for each insecticide and the distance between the sampling sites of each insect population were used to determine the spatial dependence of insecticide resistance in the tomato pinworm. The distance between the sampling sites of each insect population were determined using geographic coordinates determined by a global position system (GPS 12XL; Garmin International, Olathe, KS). ${ }^{23}$ The semi-variograms were estimated from the $L_{50}$ semi-variance data of each population, for each insecticide, and used as dependent variables in regression analysis, with the distance between sampling sites as an independent variable. The first inflection point of the semi-variogram curve represents the maximum distance of interference between populations of the tomato pinworm regarding susceptibility to a given insecticide. ${ }^{24}$

\section{RESULTS}

\subsection{Insecticide resistance}

The tomato pinworm populations exhibited only low levels of resistance $(<12$-fold $)$ to the neurotoxic insecticides abamectin (1.14-8.9-fold) and spinosad (1.2-4.8-fold) and to the pyrethroids 
Table 1. Relative toxicity of bifenthrin, permethrin and deltamethrin + triazophos to populations of the tomato pinworm $T$. absoluta, from different biomes. An asterisk following the resistance ratio at $\mathrm{LC}_{50}$ indicates a significant level of resistance

\begin{tabular}{|c|c|c|c|c|c|c|c|c|}
\hline & & Population & $n$ & Slope \pm SEM & $\mathrm{LC}_{50}(95 \% \mathrm{FL}) \mu \mathrm{g} \mathrm{Al} \mathrm{mL}{ }^{-1}$ & $\mathrm{RR}_{50}(95 \% \mathrm{CL})$ & $\chi^{2}$ & $P$ \\
\hline \multirow[t]{7}{*}{ Bifenthrin } & Semi-arid & Camocim de São Felix & 200 & $1.24 \pm 0.17$ & $99.97(68.98-156.13)$ & $11.36(7.17-17.99)^{*}$ & 3.23 & 0.36 \\
\hline & Savannah & Goianápolis & 200 & $2.63 \pm 0.34$ & $8.80(6.62-10.93)$ & $1.00(0.71-1.40)$ & 2.19 & 0.53 \\
\hline & & Uberlândia & 240 & $1.90 \pm 0.24$ & $32.14(24.37-40.85)$ & $3.65(2.59-5.16)^{*}$ & 1.79 & 0.77 \\
\hline & Atlantic forest & Santa Tereza & 280 & $2.81 \pm 0.32$ & $14.68(12.71-17.77)$ & $1.67(1.25-2.23)^{*}$ & 2.09 & 0.91 \\
\hline & & Viçosa & 200 & $5.58 \pm 0.96$ & $32.18(28.70-36.13)$ & $3.66(2.81-4.76)^{*}$ & 0.01 & 0.99 \\
\hline & & São João da Barra & 200 & $3.38 \pm 0.53$ & $26.86(19.47-33.24)$ & $3.05(2.16-4.31)^{*}$ & 0.5 & 0.92 \\
\hline & & Paulínia & 240 & $1.77 \pm 0.26$ & $26.50(20.70-36.04)$ & $3.01(2.11-4.30)^{*}$ & 1.65 & 0.80 \\
\hline \multirow[t]{7}{*}{ Permethrin } & Semi-arid & Camocim de São Felix & 280 & $1.29 \pm 0.14$ & 736.31 (534.93-1309) & $12.48(7.14-21.80)^{*}$ & 2.75 & 0.74 \\
\hline & Savannah & Goianápolis & 200 & $1.23 \pm 0.15$ & $79.01(47.62-118.15)$ & $1.34(0.71-2.52)$ & 2.54 & 0.47 \\
\hline & & Uberlândia & 240 & $1.53 \pm 0.17$ & $247.51(169.57-338.62)$ & $4.19(2.38-7.40)^{*}$ & 1.1 & 0.89 \\
\hline & Atlantic forest & Santa Tereza & 280 & $2.53 \pm 0.31$ & $411.70(333.91-488.38)$ & $6.98(4.26-11.43)^{*}$ & 1.88 & 0.75 \\
\hline & & Viçosa & 200 & $1.06 \pm 0.12$ & $59.01(36.05-92.48)$ & $1.00(0.52-1.91)^{*}$ & 2.95 & 0.34 \\
\hline & & São João da Barra & 280 & $3.35 \pm 0.34$ & $360.03(310.11-414.17)$ & $6.10(3.78-9.86)^{*}$ & 2.89 & 0.71 \\
\hline & & Paulínia & 300 & $2.61 \pm 0.29$ & $258.49(196.77-320.93)$ & $4.38(2.62-7.33)^{*}$ & 4.99 & 0.41 \\
\hline \multirow{7}{*}{$\begin{array}{c}\text { Deltamethrin }+ \\
\text { triazophos }\end{array}$} & Semi-arid & Camocim de São Felix & 200 & $9.96 \pm 0.05$ & $12.46(11.41-13.61)$ & $1.56(1.15-2.13)^{*}$ & 2.91 & 0.09 \\
\hline & Savannah & Goianápolis & 200 & $1.59 \pm 0.25$ & $8.83(6.56-12.26)$ & $1.11(0.77-1.58)$ & 2.21 & 0.53 \\
\hline & & Uberlândia & 240 & $2.30 \pm 0.39$ & $7.98(6.32-9.74)$ & $1.00(0.75-1.33)$ & 2.34 & 0.67 \\
\hline & Atlantic forest & Santa Tereza & 200 & $2.14 \pm 0.40$ & $12.13(9.56-15.89)$ & $1.52(1.11-2.07)^{*}$ & 1.2 & 0.54 \\
\hline & & Viçosa & 200 & $17.41 \pm 2.79$ & $10.61(10.10-11.01)$ & $1.33(1.08-1.63)^{*}$ & 0.39 & 0.94 \\
\hline & & São João da Barra & 200 & $2.75 \pm 0.66$ & $12.96(9.85-15.50)$ & $1.62(1.23-2.15)^{*}$ & 2.18 & 0.53 \\
\hline & & Paulínia & 240 & $3.38 \pm 0.52$ & $10.20(8.87-11.53)$ & $1.28(1.01-1.62)^{*}$ & 1.15 & 0.88 \\
\hline
\end{tabular}

Table 2. Relative toxicity of abamectin, spinosad and indoxacarb to populations of the tomato pinworm $T$. absoluta from different biomes. An asterisk following the resistance ratio at $\mathrm{LC}_{50}$ indicates a significant level of resistance

\begin{tabular}{|c|c|c|c|c|c|c|c|c|}
\hline & & Population & $n$ & Slope \pm SEM & $\mathrm{LC}_{50}(95 \% \mathrm{FL}) \mu \mathrm{g} \mathrm{Al} \mathrm{mL}^{-1}$ & $\mathrm{RR}_{50}(95 \% \mathrm{CL})$ & $\chi^{2}$ & $P$ \\
\hline \multirow[t]{7}{*}{ Abamectin } & Semi-arid & Camocim de São Felix & 280 & $2.68 \pm 0.30$ & $0.32(0.27-0.37)$ & $1.14(0.62-2.08)$ & 3.22 & 0.66 \\
\hline & Savannah & Goianápolis & 240 & $0.76 \pm 0.10$ & $0.41(0.21-0.45)$ & $1.47(0.64-3.41)$ & 1.13 & 0.88 \\
\hline & & Uberlândia & 240 & $0.98 \pm 0.13$ & $0.28(0.15-0.51)$ & $1.00(0.44-2.28)$ & 1.50 & 0.82 \\
\hline & Atlantic forest & Santa Tereza & 200 & $1.46 \pm 0.21$ & $0.73(0.44-1.73)$ & $2.60(1.19-5.70)^{*}$ & 1.34 & 0.71 \\
\hline & & Viçosa & 240 & $1.89 \pm 0.22$ & $2.51(1.71-3.86)$ & $8.92(4.58-17.38)^{*}$ & 0.64 & 0.95 \\
\hline & & São João da Barra & 240 & $2.07 \pm 0.28$ & $0.37(0.25-0.51)$ & $1.34(0.68-2.62)$ & 2.23 & 0.69 \\
\hline & & Paulínia & 280 & $2.76 \pm 0.55$ & $0.47(0.30-0.61)$ & $1.68(0.87-3.25)$ & 0.82 & 0.93 \\
\hline \multirow[t]{7}{*}{ Spinosad } & Semi-arid & Camocim de São Felix & 200 & $3.05 \pm 0.32$ & $1.44(1.17-1.77)$ & $3.09(2.02-4.71)^{*}$ & 0.59 & 0.89 \\
\hline & Savannah & Goianápolis & 240 & $1.49 \pm 0.15$ & $0.66(0.44-0.99)$ & $1.42(0.82-2.44)$ & 3.97 & 0.40 \\
\hline & & Uberlândia & 200 & $2.72 \pm 0.30$ & $2.26(1.81-2.80)$ & $4.84(3.16-7.41)^{*}$ & 3.32 & 0.34 \\
\hline & Atlantic forest & Santa Tereza & 200 & $1.14 \pm 0.18$ & $0.55(0.28-0.88)$ & $1.18(0.62-2.27)$ & 2.53 & 0.46 \\
\hline & & Viçosa & 280 & $1.54 \pm 0.18$ & $1.75(0.80-3.18)$ & $3.74(1.75-7.98)^{*}$ & 1.38 & 0.92 \\
\hline & & São João da Barra & 240 & $1.75 \pm 0.18$ & $0.57(0.43-0.75)$ & $1.22(0.77-1.93)$ & 1.22 & 0.87 \\
\hline & & Paulínia & 240 & $1.73 \pm 0.26$ & $0.46(0.29-0.64)$ & $1.00(0.59-1.69)$ & 1.95 & 0.74 \\
\hline \multirow[t]{7}{*}{ Indoxacarb } & Semi-arid & Camocim de São Felix & 200 & $1.49 \pm 0.19$ & $1.62(1.00-2.54)$ & $4.09(2.14-7.79)^{*}$ & 1.22 & 0.74 \\
\hline & Savannah & Goianápolis & 200 & $2.45 \pm 0.33$ & $1.51(1.22-1.90)$ & $3.81(2.08-7.00)^{*}$ & 2.99 & 0.39 \\
\hline & & Uberlândia & 240 & $0.92 \pm 0.10$ & $10.80(6.06-17.67)$ & $27.25(12.59-58.99)^{*}$ & 2.01 & 0.73 \\
\hline & Atlantic forest & Santa Tereza & 280 & $1.25 \pm 0.20$ & $0.39(0.19-0.65)$ & $1.00(0.45-2.24)$ & 0.78 & 0.97 \\
\hline & & Viçosa & 240 & $1.1 \pm 0.13$ & $5.40(3.04-8.56)$ & $13.61(6.37-29.09)^{*}$ & 1.44 & 0.83 \\
\hline & & São João da Barra & 200 & $1.39 \pm 0.19$ & $10.82(7.02-15.62)$ & $27.29(13.72-54.29)^{*}$ & 4.66 & 0.19 \\
\hline & & Paulínia & 280 & $1.01 \pm 0.12$ & $1.53(0.98-2.26)$ & $3.87(1.92-7.78)^{*}$ & 8.48 & 0.20 \\
\hline
\end{tabular}

bifenthrin (1.7-11.4-fold) and permethrin (1.3-12.5-fold), and negligible levels of resistance to the mixture deltamethrin + triazophos (1.1-1.6-fold) (Tables 1 and 2). Pyrethroid resistance prevailed in the semi-arid region, while the highest levels of abamectin resistance were observed in an insect population from the Atlantic forest, and the highest level of spinosad resistance was observed in the Brazilian savannah. Among the neurotoxic insecticides, indoxacarb exhibited the highest levels of resistance (between 13.6- and 27.3-fold) in the pinworm populations, reaching moderate levels in the Atlantic forest and Brazilian savannah. In spite of the overall low levels of insecticide resistance to neurotoxic compounds (except for indoxacarb), the slopes of 


\begin{tabular}{|c|c|c|c|c|c|c|c|c|}
\hline & & Population & $n$ & Slope \pm SEM & $\mathrm{LC}_{50}(95 \% \mathrm{FL}) \mu \mathrm{g} \mathrm{Al} \mathrm{mL}-1$ & $\mathrm{RR}_{50}(95 \% \mathrm{CL})$ & $\chi^{2}$ & $P$ \\
\hline \multirow[t]{7}{*}{ Diflubenzuron } & Semi-arid & Camocim de São Felix & 300 & $1.17 \pm 0.15$ & 20543 (13 199-30 609) & $57.39(26.10-126.19)^{*}$ & 0.92 & 0.81 \\
\hline & Savannah & Goianápolis & 240 & $0.75 \pm 0.07$ & $358(178.85-709.10)$ & $1.00(0.38-2.60)$ & 0.97 & 0.61 \\
\hline & & Uberlândia & 240 & $0.68 \pm 0.11$ & $1182(642.41-2119)$ & $3.30(1.37-7.95)^{*}$ & 2.12 & 0.34 \\
\hline & Atlantic forest & Santa Tereza & 300 & $0.40 \pm 0.04$ & $924.42(365.38-2277)$ & $2.58(0.84-7.89)$ & 2.30 & 0.51 \\
\hline & & Viçosa & 300 & $1.80 \pm 0.36$ & $842.64(598.03-1070)$ & $2.35(1.14-4.86)^{*}$ & 2.07 & 0.55 \\
\hline & & São João da Barra & 240 & $1.26 \pm 0.24$ & 12915 (8411-21 523) & $36.08(16.18-80.45)^{*}$ & 0.77 & 0.68 \\
\hline & & Paulínia & 300 & $0.88 \pm 0.25$ & 1019 (230.96-1779) & $2.85(1.01-8.01)^{*}$ & 0.23 & 0.97 \\
\hline \multirow[t]{7}{*}{ Teflubenzuron } & Semi-arid & Camocim de São Felix & 360 & $1.18 \pm 0.19$ & $2.79(1.42-4.22)$ & $2.95(0.98-8.90)$ & 1.88 & 0.75 \\
\hline & Savannah & Goianápolis & 240 & $0.58 \pm 0.09$ & $210.70(67.53-543.09)$ & $222.67(55.51-893.15)^{*}$ & 0.33 & 0.84 \\
\hline & & Uberlândia & 240 & $0.75 \pm 0.11$ & $0.94(0.27-2.21)$ & $1.00(0.25-4.02)$ & 0.57 & 0.75 \\
\hline & Atlantic forest & Santa Tereza & 240 & $1.27 \pm 0.22$ & $3.02(1.56-4.54)$ & $3.20(1.07-9.59)^{*}$ & 1.36 & 0.50 \\
\hline & & Viçosa & 240 & $0.66 \pm 0.16$ & $47.94(27.22-108.39)$ & $50.67(16.05-159.93)^{*}$ & 1.33 & 0.51 \\
\hline & & São João da Barra & 400 & $0.56 \pm 0.09$ & $3.75(1.74-7.37)$ & $3.96(1.20-13.13)^{*}$ & 1.30 & 0.93 \\
\hline & & Paulínia & 300 & $0.63 \pm 0.08$ & $65.28(29.53-149.54)$ & $68.99(19.60-242.89)^{*}$ & 1.86 & 0.60 \\
\hline \multirow[t]{7}{*}{ Triflumuron } & Semi-arid & Camocim de São Felix & 240 & $1.49 \pm 0.19$ & $1.62(1.00-2.54)$ & $4.09(2.14-7.79)^{*}$ & 1.22 & 0.74 \\
\hline & Savannah & Goianápolis & 420 & $0.38 \pm 0.06$ & $162.54(50.68-392.86)$ & $1.00(0.26-3.89)$ & 1.73 & 0.88 \\
\hline & & Uberlândia & 300 & $3.10 \pm 0.46$ & $15973(13049-18691)$ & $98.27(37.02-260.85)^{*}$ & 3.19 & 0.36 \\
\hline & Atlantic forest & Santa Tereza & 240 & $1.87 \pm 0.35$ & 1924 (1134-2619) & $11.84(4.22-33.23)^{*}$ & 0.36 & 0.83 \\
\hline & & Viçosa & 240 & $0.65 \pm 0.29$ & $352.54(139.37-665975)$ & $2.17(0.45-10.56)$ & 1.10 & 0.29 \\
\hline & & São João da Barra & 240 & $1.99 \pm 0.50$ & 25015 (19 160-40 146) & $153.91(56.09-422.27)^{*}$ & 0.53 & 0.76 \\
\hline & & Paulínia & 360 & $1.04 \pm 0.20$ & $681.19(263.67-1144)$ & $4.26(1.34-13.56)^{*}$ & 1.70 & 0.79 \\
\hline \multirow[t]{7}{*}{ B. thuringiensis } & Semi-arid & Camocim de São Felix & 300 & $1.17 \pm 0.15$ & $88.11(48.17-137.37)$ & $1.27(0.55-2.95)$ & 0.77 & 0.81 \\
\hline & Savannah & Goianápolis & 240 & $1.57 \pm 0.25$ & $176.72(108.68-239.78)$ & $2.55(1.18-5.51)^{*}$ & 5.22 & 0.61 \\
\hline & & Uberlândia & 240 & $1.54 \pm 0.28$ & $69.41(25.72-118.54)$ & $1.00(0.38-2.61)$ & 2.66 & 0.34 \\
\hline & Atlantic forest & Santa Tereza & 300 & $0.37 \pm 0.14$ & $552.51(150.22-1886603)$ & $7.96(0.89-71.17)$ & 0.30 & 0.51 \\
\hline & & Viçosa & 300 & $2.19 \pm 0.20$ & 337.70 (281.77-404.61) & $4.87(2.41-9.82)^{*}$ & 2.34 & 0.55 \\
\hline & & São João da Barra & 240 & $1.58 \pm 0.29$ & $81.69(29.83-140.17)$ & $1.18(0.45-3.09)$ & 2.70 & 0.68 \\
\hline & & Paulínia & 300 & $2.47 \pm 0.28$ & $390.92(319.98-466.44)$ & $5.63(2.79-11.39)^{*}$ & 4.69 & 0.97 \\
\hline
\end{tabular}

the concentration-mortality curves for each insecticide varied significantly among populations, indicating significant potential for further selection for insecticide resistance in some pinworm field populations (Tables 1 and 2). Such variation also exists for indoxacarb (Table 2), and more curiously for the deltamethrin + triazophos mixture (Table 1).

Resistance to $B$. thuringiensis was also low among the insect populations, but very high concentrations were required in the bioassays (Table 3 ). In contrast, moderate to high levels of resistance to chitin synthesis inhibitors (up to 222.7-fold) were observed in some pinworm populations. Such moderate to high levels of resistance were distributed among the three macroregions of population sampling. The slopes of the concentration-mortality curves varied among populations, indicating heterogeneous response to both chitin synthesis inhibitors and $B$. thuringiensis (Table 3).

\subsection{Likehood of insecticide control failure}

Abamectin, deltamethrin + triazophos and spinosad exhibited the expected efficacy against the pinworm field populations at the recommended label rates (Table 4). However, B. thuringiensis, diflubenzuron, triflumuron and permethrin exhibited control failures against all pinworm populations tested, while bifenthrin, indoxacarb and the chitin synthesis inhibitor teflubenzuron exhibited control failures against some of the pinworm populations (Table 4).

\subsection{Relationship between weather conditions and insecticide resistance}

Among the weather variables, only rain, average air temperature and insolation exhibited significant correlations $(P<0.05)$ with insecticide resistance in the pinworm populations. The principal component analysis (PCA) with $\mathrm{LC}_{50}$ values for each insecticide and insect population and the three weather conditions at each population sampling site generated four axes explaining $90.7 \%$ of the observed variance. The PCA diagram allows the recognition of four groups of correlated trends in insecticide resistance and the potential influence of weather conditions on such a phenomenon (Fig. 2). Resistance levels to deltamethrin + triazophos, permethrin, diflubenzuron and bifenthrin are correlated and vary together, as opposed to resistance to $B$. thuringiensis and abamectin; these two insecticide resistance groups are negatively correlated and relatively independent of the other two groups. Resistance levels to triflumuron, spinosad and indoxacarb vary together or are positively correlated, and they are negatively correlated with teflubenzuron resistance. Rainfall is positively correlated with $B$. thuringiensis and abamectin resistance, and negatively correlated with resistance to bifenthrin, diflubenzuron, permethrin and deltamethrin + triazophos. Insolation exhibits the opposite correlation, but on a smaller scale, while air temperature is positively correlated with resistance to indoxacarb, spinosad and triflumuron, again on a small scale, with the opposite correlation with resistance to teflubenzuron. 
Table 4. Estimated insecticide mortality (\%) of populations of the tomato pinworm Tuta absoluta using Brazilian recommended label rates

\begin{tabular}{|c|c|c|c|c|c|c|c|c|}
\hline & \multicolumn{4}{|c|}{ Brazilian savannah } & \multicolumn{2}{|c|}{ Atlantic forest } & \multicolumn{2}{|r|}{ Semi-arid } \\
\hline & Insecticides & Uberlândia & Goianápolis & Paulínia & S. João da Barra & Viçosa & Santa Tereza & C. de São Félix \\
\hline \multirow[t]{6}{*}{ Neurotoxic } & Abamectin & 100.0 & 100.0 & 100.0 & 100.0 & 100.0 & 100.0 & 100.0 \\
\hline & Bifenthrin & $64.0^{\mathrm{a}}$ & 97.0 & $70.0^{\mathrm{a}}$ & 83.0 & 85.0 & 93.0 & $35.0^{\mathrm{a}}$ \\
\hline & Delmethrin + triazophos & 91.5 & 80.0 & 95.0 & 86.5 & 100.0 & 82.0 & 95.0 \\
\hline & Indoxacarb & $67.0^{\mathrm{a}}$ & 100.0 & 91.0 & $70.0^{\mathrm{a}}$ & $67.5^{\mathrm{a}}$ & 100.0 & 96.0 \\
\hline & Permethrin & $30.0^{\mathrm{a}}$ & $25.0^{\mathrm{a}}$ & $20.0^{\mathrm{a}}$ & $4.00^{\mathrm{a}}$ & $60.0^{\mathrm{a}}$ & $6.00^{\mathrm{a}}$ & $15.0^{\mathrm{a}}$ \\
\hline & Spinosad & 100.0 & 100.0 & 100.0 & 100.0 & 100.0 & 100.0 & 100.0 \\
\hline \multirow[t]{4}{*}{ Chitin synthesis inhibitor } & Diflubenzuron & $35.0^{\mathrm{a}}$ & $77.0^{\mathrm{a}}$ & $59.5^{\mathrm{a}}$ & $10.0^{\mathrm{a}}$ & $64.5^{\mathrm{a}}$ & $53.0^{\mathrm{a}}$ & $20.0^{\mathrm{a}}$ \\
\hline & Teflubenzuron & 86.0 & $34.0^{\mathrm{a}}$ & 92.0 & $50.0^{\mathrm{a}}$ & $68.0^{\mathrm{a}}$ & $20.0^{\mathrm{a}}$ & 91.0 \\
\hline & Triflumuron & $0.00^{\mathrm{a}}$ & $51.0^{\mathrm{a}}$ & $25.5^{\mathrm{a}}$ & $0.00^{\mathrm{a}}$ & $45.0^{\mathrm{a}}$ & $4.00^{\mathrm{a}}$ & $52.0^{\mathrm{a}}$ \\
\hline & B. thuringiensis & $44.1^{\mathrm{a}}$ & $33.7^{\mathrm{a}}$ & $1.12^{\mathrm{a}}$ & $46.7^{\mathrm{a}}$ & $7.00^{\mathrm{a}}$ & $2.34^{\mathrm{a}}$ & $46.2^{\mathrm{a}}$ \\
\hline
\end{tabular}

${ }^{a}$ Mortality significantly lower than $80 \%$ because the label rate is lower than the lower threshold of the insecticide $\mathrm{LC}_{80}$ fiducial interval for the population.

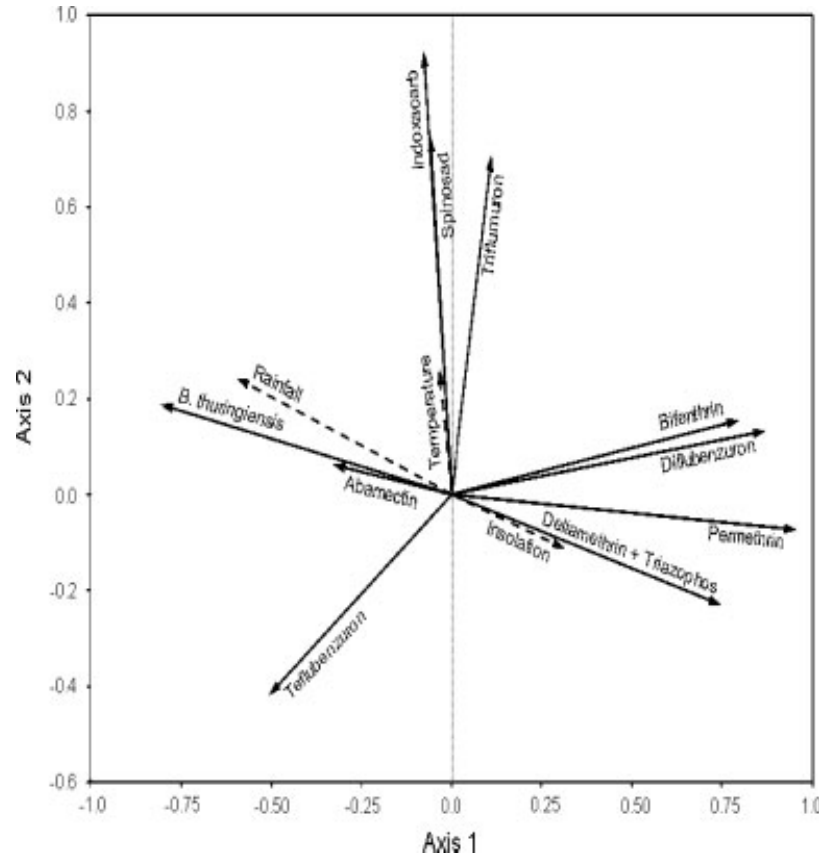

Figure 2. Ordination diagram of the principal component analysis (PCA) of the effect of the air temperature $\left({ }^{\circ} \mathrm{C}\right)$, rainfall $\left(\mathrm{mm}\right.$ year $\left.{ }^{-1}\right)$ and insolation ( $\mathrm{h}$ day $^{-1}$ ) of the sampling sites of the populations of Tuta absoluta in the $\mathrm{LC}_{50}$ of the insecticides. The length of the vector is proportional to the importance of the variable. Variables with positive correlation have vectors with the same direction and orientation. Variables with negative correlation have vectors with the same direction and opposite orientation. When the angle between the vectors is $90^{\circ}$, the variables are not correlated.

\subsection{Spatial dependence of insecticide resistance}

Significant $(P<0.05)$ semi-variogram models relating the pinworm $\mathrm{LC}_{50}$ values to distance between sampling sites were obtained for only two insecticides, the pyrethroids bifenthrin and permethrin. The first inflection points for both models were at distances of 1027 and $1403 \mathrm{~km}$ for bifenthrin and permethrin respectively (Fig. 3 ). Therefore, these were the maximum interference distances between resistance levels of pinworm sampling sites.

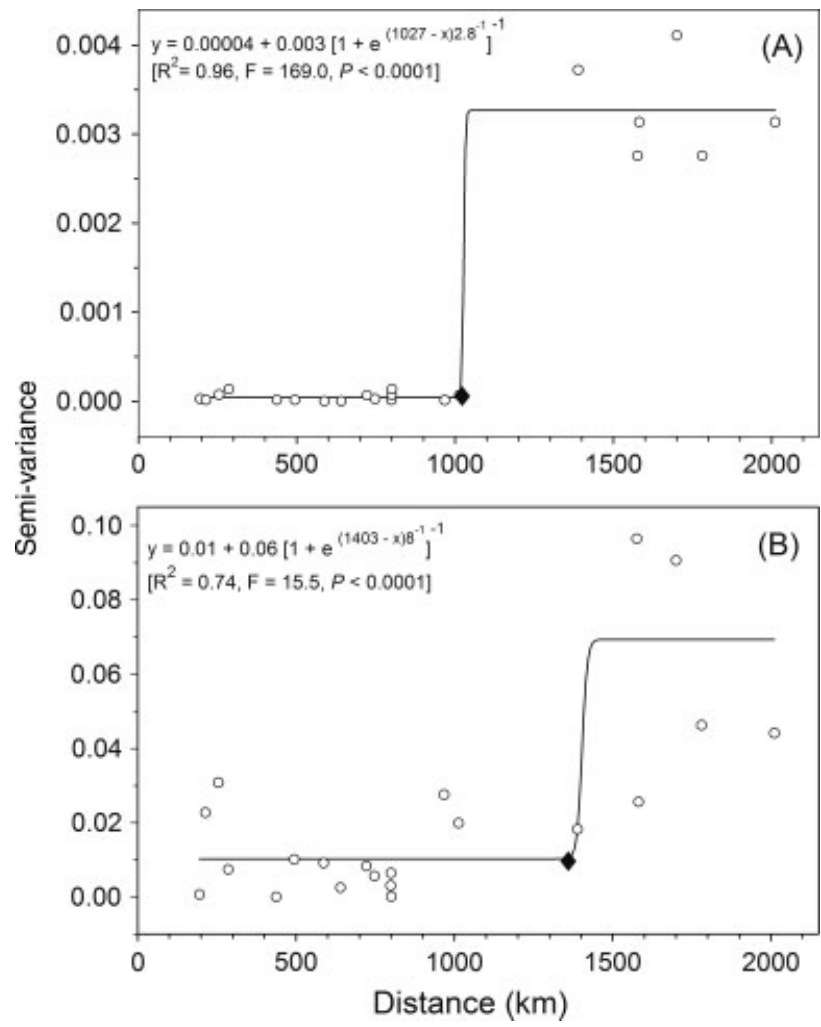

Figure 3. Semi-variogram of the $L C_{50}$ of $(A)$ bifenthrin and (B) permethrin according to the distance between the sampling sites of the field populations of tomato pinworm Tuta absoluta. First inflection point of the semi-variogram curve (representing the maximum distance of interference of insecticide resistance).

\section{DISCUSSION}

Previous studies of insecticide resistance in the tomato pinworm T. absoluta have focused on either impregnated filter paper bioassays or topical applications, both approaches using technicalgrade insecticides. ${ }^{8-13}$ These earlier studies did not survey field resistance to indoxacarb, spinosad, chitin synthesis inhibitors, B. thuringiensis and insecticide mixtures. ${ }^{8-13}$ Here, suitable methods were successfully developed for assessing pinworm 
resistance to fast-acting and slow-acting insecticides using commercial insecticide formulations in approaches resembling more closely the field application of these compounds. These two methods of insecticide bioassays made it possible to recognise pinworm resistance not only to already studied compounds, such as permethrin and abamectin, but also to newer neutorotoxic insecticides (indoxacarb and spinosad), to a mixture of neurotoxic insecticides (permethrin + triazophos), to chitin synthesis inhibitors and to $B$. thuringiensis.

The same insecticides are usually employed in the different Brazilian regions at a given time, but at different application frequencies, and their use pattern changes with time - abamectin, cartap and permethrin have been heavily used in the past, but were later replaced with insect growth regulators (mainly chitin synthesis inhibitors), and more recently with spinosad. ${ }^{1-3,6-10}$ Among the insecticides tested in the present study, only abamectin and permethrin were previously subjected to insecticide resistance studies in populations of the tomato pinworm in Brazil. $8,10,12$ Low levels of resistance to both compounds were reported in this country, and abamectin resistance was also reported in Argentina. 8,12 Here, low levels of resistance to both these insecticides were also observed, probably reflecting their current low use in the country compared with the late 1980s. At present, chitin synthesis inhibitors are the insecticides most frequently used against the tomato pinworm in Brazil, although the use of spinosad is increasing. Therefore, the detection of resistance to these compounds was expected, although the levels of resistance were still low at the majority of the sampling sites. However, resistance to chitin synthesis inhibitors does occur across all of the tomatoproducing regions of the country, and high levels of resistance, particularly to triflumuron and teflubenzuron, were detected at sampling sites in the Brazilian savannah and Atlantic forest.

Indoxacarb resistance is also a concern in the Brazilian savannah and Atlantic forest, although the resistance levels are lower than those of chitin synthesis inhibitors, and at a smaller number of sampling sites within these two regions. Resistance to B. thuringiensis was also detected at low levels, but high insecticide concentrations were required for pinworm control, and control failures are likely to occur with the use of this insecticide, in spite of the low levels of resistance observed. Although the 7 day exposure bioassays used may have limited the expression of the full potential of such slow-acting insecticide, the relatively low efficacy of $B$. thuringiensis may lead to such control failures even with low levels of resistance, which may be minimised by mixing $B$. thuringiensis with mineral oil. ${ }^{25,26}$ Bifenthrin, and particularly permethrin, also exhibited control failure against the tomato pinworm, in spite of the low levels of resistance to these compounds in the insect populations surveyed. Indoxacarb also exhibited control failures, but, unlike permethrin, where the problem was generalised, this shortcoming took place only with the populations more resistant to this insecticide - Viçosa and São João da Barra in the Atlantic forest region, and Uberlândia in the Brazilian savannah. Control failures were also widespread for the chitin synthesis inhibitors, and more drastically so for triflumuron, followed by diflubenzuron, a likely consequence of the more intensive use of the first compound. In contrast, high levels of efficacy and no pinworm control failure were observed for spinosad, deltamethrin + triazophos and even for abamectin, for which insecticide resistance was previously reported both in Brazil and Argentina. $8,10,12$

Weather conditions seem to affect insecticide resistance in the tomato pinworm populations, except for teflubenzuron (which was little affected by weather conditions), which may be due to such conditions favouring the insect population and/or demanding higher insecticide use, as reported for coffee leafminer Leucoptera coffeella (Lepidoptera: Lyonetiidae). ${ }^{27,28}$ The tomato pinworm exhibits high reproductive performance under warmer and drier conditions, usually requiring higher rates of insecticide use during this period of the year (i.e. the dry season in Brazil). ${ }^{6,29}$ Indeed resistance levels to indoxacarb, spinosad and triflumuron are positively correlated and favoured by high temperatures, while bifenthrin, diflubenzuron, permethrin and deltamethrin + triazophos are also correlated and negatively affected by rainfall (and also favoured by higher insolation). In contrast, high rainfall seems to favour abamectin and particularly $B$. thuringiensis resistance. This may be due to insecticide removal by the falling rain, requiring additional spraying of an insecticide already exhibiting lower levels of efficacy in the case of B.thuringiensis. Lower insolation, in contrast, may favour persistence of both $B$. thuringiensis and abamectin, as earlier suggested by field experiments, $^{30}$ leading to higher exposure and thus selection for resistance to these compounds under such conditions. High insolation may also favour synergism between some insecticides and tomato defence compounds, the production of which is higher under these conditions. ${ }^{31,32}$ However, this hypothesis needs proper testing.

The geographical distribution of insecticide resistance may be a consequence of dispersal and thus spatial dependence among populations. ${ }^{28,33}$ The closer the sampling sites, the more similar will be the insecticide resistance profile among the insect populations collected from these sites if spatial dependence really occurs in the tomato pinworm. No spatial dependence was observed for the majority of the insecticides tested, suggesting that local factors, including frequency of insecticide use and weather conditions, play a major role in the evolution of pinworm resistance to insecticides. A similar conclusion was also reached for insecticide resistance in the maize weevil Sitophilus zeamais (Coleoptera: Curculionidae). ${ }^{33}$ Curiously, though, resistance to both pyrethroids bifenthrin and permethrin in the tomato pinworm populations did exhibit spatial dependence. Maximum distances of interference were 1027 and $1403 \mathrm{~km}$ for bifenthrin and permethrin resistance respectively, which is rather large. Such distances of interference suggest a high capacity for population dispersal in this species, which is supported by the pattern of this species dispersal in Brazil by the late 1970s, spreading over $2000 \mathrm{~km}$ in 2 years, and also in southern Europe and northern Africa, where the tomato pinworm spread to several countries in only 3 years. ${ }^{5,34}$

In conclusion, insecticide resistance in field populations of the tomato pinworm prevails for the insecticides most frequently used against them nowadays - the chitin synthesis inhibitors (diflubenzuron, triflumuron and teflubenzuron). Insecticides used in the past are still viable, and interruptions of insecticide use seem to be a sound strategy for managing insecticide resistance in the tomato pinworm if no positive cross-resistance (or multiple resistance) exists with the introduced insecticides. Furthermore, local selection favoured by weather conditions and dispersal seem important for insecticide resistance evolution among Brazilian populations of T. absoluta and should be considered in designing pest management programmes. Variation for further selection for insecticide resistance does exist in field populations of the tomato pinworm in all of the major tomato-producing regions in Brazil, leading to a high risk of insecticide resistance evolution. Such risk is particularly high throughout the year in the Brazilian savannah, and also high in the Atlantic forest and semi-arid areas, 
but only during the dry season, dropping to a moderate level during the rainy season. Only insecticides not exhibiting control failures should be used in such conditions, and a higher diversity of insecticides (out of the cross- and multiple-resistance spectra) should be used in rotation to minimise the risk of evolution of insecticide resistance.

\section{ACKNOWLEDGEMENTS}

The authors thank the Brazilian branch of the Insecticide Resistance Action Committee (IRAC-BR), the National Council of Scientific and Technological Development (CNPq), the CAPES Foundation (Brazilian Ministry of Education) and the Minas Gerais State Foundation for Research Aid (FAPEMIG) for the financial support and scholarships provided. The IRAC-BR and affiliated chemical companies also assisted in the field sampling of insect populations and provision of insecticide formulations, for which the authors are also grateful. The comments and suggestions provided by $\mathrm{Dr} \mathrm{SH}$ Lee and two anonymous reviewers are greatly appreciated.

\section{REFERENCES}

1 Giordano LB and Silva C, Hibridação em tomate, in Hibridação Artificial de Plantas, ed. by Borém A. Universidade Federal Viçosa, Viçosa, Brazil, pp. 463-480 (1999).

2 Picanço MC, Bacci L, Crespo ALB, Miranda MMM and Martins JC, Effect of integrated pest management practices on tomato Lycopersicon esculentum production and preservation of natural enemies of pests. Agric For Entomol 9:201 - 212 (2007)

3 Picanço MC, Bacci L, Silva EM, Morais EGF, Silva GA and Silva NR, Manejo integrado das pragas do tomateiro no Brasil, in Tomate. Tecnologia de Produção, ed. by Silva DJH and Vale FXR. Universidade Federal de Viçosa, Viçosa, Brazil, pp. 199-232 (2007).

4 First Record of Tuta absoluta in Algeria. [Online]. European Plant Protection Organization, EPPO Reporting Service 2008/135 (2008). Available: http://archives.eppo.org/EPPOReporting/2008/Rse-0807.pdf [10 August 2010].

5 Garcia Marí $\mathrm{F}$ and Vercher R, Descripción, origin y expansión de Tuta absoluta (Lepidoptera; Gelechiidae). Phytoma-España 217:16-20 (2010).

6 Picanço MC, Leite GLD, Guedes RNC and Silva EA, Yield loss in trellised tomato affected by insecticidal sprays and plant spacing. Crop Prot 17:447-452 (1998).

7 Guedes RNC, Picanço MC, Matioli AL and Rocha DM, Efeito de insecticides e sistemas de condução do tomateiro no control de Scrobipalpuloides absoluta (Meyrick) (Lepidoptera: Gelechiidae). An Soc Entomol Bras 23:321 - 325 (1994).

8 Siqueira HAA, Guedes RNC and Picanço MC, Insecticide resistance in populations of Tuta absoluta (Lepdoptera: Gelechiidae). Agric For Entomol 2:147-153 (2000).

9 Siqueira HAA, Guedes RNC and Picanço MC, Cartap resistance and synergism in populations of Tuta absoluta (Lep., Gelechiidae). J Appl Entomol 124:233-238 (2000).

10 Siqueira HAA, Guedes RNC, Fragoso DB and Magalhaes LC, Abamectin resistance and synergism in Brazilian populations of Tuta absoluta (Meyrick) (Lepidoptera: Gelechiidae). Int J Pest Manag 47:247-251 (2001).

11 Salazar ER and Araya JE, Detección de resistencia a insecticidas en la polilla del tomate. Simiente 67:8-22 (1997).

12 Lietti MMM, Botto $\mathrm{E}$ and Alzogaray RA, Insecticide resistance in Argentine populations of Tuta absoluta (Meyrick) (Lepidoptera: Gelechiidae). Neotrop Entomol 34:113-119 (2005).

13 Salazar ER and Araya JE, Respuesta de la polilla del tomate, Tuta absoluta (Meyrick), a insecticidas en Arica. Agric Téc 61:429-435 (2001).
14 Leite GLD, Picanço MC, Azevedo AA, Zurita $\mathrm{Y}$ and Marquini F, Oviposicion y mortalidad de Tuta absoluta en Lycopersicon hirsutum. Manejo Integrado de Plagas 22:26-34 (1998).

15 Andrei E, Compêndio de Defensivos Agrícolas, 8th edition. Organização Andrei, São Paulo, Brazil (2009).

16 AGROFIT: Sistema de Agrotóxicos Fitossanitários. [Online]. Ministério da Agricultura, Pecuária e Abastecimento, Coordenação Geral de Agrotóxicos e Afins/DFIA/DAS, Brasília, Brazil. Available: http://extranet.agricultura.gov.br/agrofit_cons/principal_agrofit_ cons [8 August 2010].

17 Reynolds SE, The cuticule, growth regulators and moulting in insects: the essential background to the action of acylurea insecticides. Pestic Sci 20:131-146 (1987).

18 Fisk T and Wright DJ, Response of Spodoptera exempta (Walk) larvae to simulated field spray applications of acylurea insect growthregulators with observations on cuticular uptake of acylureas. Pestic Sci 35:321-330 (1992).

19 SAS User's Guide: Statistics, Version 8.2. SAS Institute, Cary, NC (2001).

20 Robertson JL and Preisler HK, Pesticide Bioassays with Arthropods. CRC Press, Boca Raton, FL (1992).

21 Normas e exigências para execução de testes de produtos químicos para fins de registro no MAPA. Ministério da Agricultura e Reforma Agrária, MAPA, Brasília, Brazil (1995).

22 Ter Braak CJF, Ordination, in Data Analysis in Community and Landscape Ecology, ed. by Jongman RHG, Ter Braak CJF and Van Tongeren OFR. Cambridge University, Cambridge, UK, pp. 91 - 173 (1995).

23 Donnay JDH, Spherical Trigonometry. Interscience, New York, NY (2007).

24 Liebhold AM, Rossi RE and Kemp WP, Geostatistics and geographic information systems in applied insect ecology. Annu Rev Entomol 38:303-327 (1993).

25 Guedes RNC, Picanço MC, Guedes NMP and Madeira NR, Sinergismo do óleo mineral sobre a toxicidade de inseticidas para Scrobipalpuloides absoluta (Lepidoptera: Gelechiidae). Pesq Agropec Bras 30:313-318 (1995).

26 Picanço MC, Silva EA, Lobo AP and Leite GLD, Adição de óleo mineral a inseticidas no controle de Tuta absoluta (Meyrick) (Lepidoptera: Gelechiidae) e Helicoverpa zea (Bod.) (Lepidoptera: Noctuidae) em tomateiro. An Soc Entomol Bras 25:495-499 (1996).

27 Fragoso DB, Guedes RNC, Picanço MC and Zambolim L, Insecticide use and organophosphate resistance in the coffee leaf miner Leucoptera coffeella (Lepidoptera: Lyonetiidae). Bull Entomol Res 92:203-212 (2002).

28 Fragoso DB, Guedes RNC and Ladeira JA, Seleção na evolução de resistência a organofosforados em Leucoptera coffeella (GuérinMèneville) (Lepidoptera:Lyonetiidae). Neotrop Entomo/32:329-334 (2003).

29 Miranda MMM, Picanço MC, Zanuncio JC and Guedes RNC, Ecological life table of Tuta absoluta (Meyrick) (Lepidoptera: Gelechiidae). Biocontrol Sci Technol 8:597-606 (1998).

30 Castelo BM and França FH, Interferência da luz solar e da precipitação pluviométrica na eficiência de abamectin e cartap no control de Tuta absoluta (Meyrick) (Lepidoptera: Gelechiidae). An Soc Entomol Bras 25:489-494 (1996).

31 Jansen MPT and Stamp NE, Effects of light availability on host plant chemistry and the consequences for behavior and growth of an insect herbivore. Entomol Exp App/ 82:319-333 (1997).

32 Ecole CC, Picanço MC, Guedes RNC and Brommonschenkel SH, Effect of cropping season and possible compounds involved in the resistance of Lycopersicon hirsutum f. typicum to Tuta absoluta (Meyrick) (Lep., Gelechiidae). J Appl Entomol 125:193-200 (2001).

33 Fragoso DB, Guedes RNC and Rezende ST, Glutathione S-transferase detoxification as a potential pyrethroid resistance mechanism in the weevil, Sithophilus zeamais. Entomol Exp App/ 109:21-29 (2003).

34 Morais GJ and Normanha Filho JA, Surto de Scropipalpula absoluta (Meyrick) em tomateiro no Trópico Semi-Árido. Pesq Agropec Bras 17:503-504 (1982). 